\title{
PENGARUH DEBT TO EQUITY RATIO, RETURN ON EQUITY DAN EARNING PER SHARE TERHADAP HARGA SAHAM PERUSAHAAN REAL ESTATE DAN PROPERTI YANG TERDAFTAR DI BURSA EFEK INDONESIA PERIODE 2015-2018
}

\author{
Romy Lawandi \\ Program Studi Magister Manajemen Universitas Tarumanagara \\ romy.lawandi@yahoo.com \\ Carunia Mulya Firdausy \\ Program Studi Magister Manajemen Universitas Tarumanagara
}

Masuk : 06-12-2019, revisi : 19-12-2019 diterima untuk diterbitkan : 20-12-2019

\begin{abstract}
This study aims to analyze the influence of Debt to Equity Ratio (DER), Return on Equity (ROE), Earning per Share (EPS) simultaneously and partially to Stock Price of real estate and property company that listed on Indonesian Stock Exchange for period 2015-2018. This research used purposive sampling method and obtained 25 real estate and property company as sample. The analysis method used is multiple linear regression through SPSS 24.00 program. Results of this study shows that simultaneously Debt to Equity Ratio (DER), Return on Equity (ROE), Earning per Share (EPS) have significant influence to stock price. While Partially, only Earning per Share has significant influence to stock price. Meanwhile Debt to Equity Ratio and Return on Equity have not significant influence on stock price of real estate and property company that listed on Indonesian Stock Exchange for period 2015-2018.
\end{abstract}

Abstrak : Penelitian ini bertujuan untuk menganalisis pengaruh Debt to Equity Ratio (DER), Return on Equity (ROE), Earning per Share (EPS) terhadap harga saham secara simultan dan parsial terhadap harga saham perusahaan real estate dan properti yang terdaftar di Bursa Efek Indonesia untuk periode 2015 - 2018. Penelitian ini mengunakan metode purposive sampling dan diperoleh 25 perusahaan real estate dan properti sebagai sampel. Metode analisis yang digunakan adalah regresi linear berganda melalui program SPSS 24.00. Hasil penelitian ini menunjukkan secara simultan Debt to Equity Ratio (DER), Return on Equity (ROE), Earning per Share (EPS) berpengaruh signifikan terhadap harga saham. Sementara secara parsial hanya Earning per Share berpengaruh terhadap harga saham. Sedangkan Debt to Equity Ratio dan Return on Equity tidak berpengaruh terhadap harga saham perusahaan real estate dan properti yang terdaftar di Bursa Efek Indonesia periode 2015-2018.

Keywords : Debt to Equity Ratio (DER), Return on Equity (ROE), Earning per Share (EPS), Stock Price

\section{PENDAHULUAN}

Sebelum memutuskan berinvestasi di pasar modal, calon investor terlebih dahulu harus mempertimbangkan perkembangan return atau harga saham. Oleh karena itu, investor perlu melakukan analisis informasi untuk mengetahui faktor faktor mana saja yang menjadi penyebab naik turunnya harga saham perusahaan yang diperjual-belikan di pasar modal. Salah satu cara untuk mengukur nilai saham dapat dilakukan dengan analisis fundamental. Utomo (2016) menerangkan bahwa salah satu aspek penting analisis fundamental adalah laporan keuangan, karena dari laporan keuangan dapat memperkirakan keadaan atau kondisi keuangan perusahaan. Kondisi atau kinerja keuangan perusahaan dapat diukur dengan berbagai rasio keuangan. Analisis rasio keuangan dapat membantu investor dalam pengambilan keputusan. 
Perkembangan bisnis properti di Indonesia cukup menyita perhatian investor. Dahulu bisnis di sektor properti dianggap selalu menguntungkan, namun beberapa tahun belakangan ini pertumbuhan sektor properti rentan dipengaruhi oleh sejumlah faktor. Pergerakan rata - rata harga saham pada perusahaan real estate dan properti menunjukkan hasil yang kurang baik dimana terjadi penurunan rata - rata harga saham pada tahun 2015 hingga 2017. Penurunan rata - rata harga saham disebabkan karena daya beli masyarakat dalam bisnis properti masih belum sepenuhnya pulih (Head of Research Universal Broker, Satrio Hutomo, www.bareksa.com/Bagaimana-nasib-saham-properti-di-tahun-2017/).

Dalam penelitian ini variabel yang digunakan untuk meneliti pengaruh terhadap harga saham adalah dengan menggunakan rasio keuangan yang tercantum dalam laporan keuangan, diantaranya Debt to Equity Ratio (DER), Return on Equity (ROE) dan Earning per Share (EPS). Berdasarkan uraian permasalahan di atas, serta masih terdapatnya hasil penelitian yang tidak konsisten dengan variabel yang digunakan, maka penulis tertarik untuk melakukan penelitian lebih lanjut mengenai "Pengaruh Debt to Equity Ratio, Return on Equity dan Earning per Share Terhadap Harga Saham Perusahaan Real Estate dan Properti Yang Terdaftar di Bursa Efek Indonesia Periode 2015-2018”.

Tujuan penelitian ini adalah untuk :

a. Mengetahui pengaruh Debt to Equity Ratio (DER) terhadap harga saham pada perusahaan real estate dan properti yang terdaftar di Bursa Efek Indonesia periode 20152018

b. Mengetahui pengaruh Return on Equity (ROE) terhadap harga saham pada perusahaan real estate dan properti yang terdaftar di Bursa Efek Indonesia periode 2015-2018

c. Mengetahui pengaruh Earning per Share (EPS) terhadap harga saham pada perusahaan real estate dan properti yang terdaftar di Bursa Efek Indonesia periode 2015-2018

d. Mengetahui pengaruh Debt to Equity Ratio (DER), Earning per Share (EPS), Return on Equity (ROE) secara bersama-sama terhadap harga saham pada perusahaan real estate dan properti yang terdaftar di Bursa Efek Indonesia periode 2015-2018

\section{TINJAUAN PUSTAKA DAN HIPOTESIS}

\section{Pengaruh Debt to Equity Ratio (DER) Terhadap Harga Saham}

Besarnya rasio ini menunjukkan proporsi modal perusahaan yang diperoleh dari pembiayaan (utang) lebih besar dibandingkan dengan sumber-sumber yang lain. Semakin tinggi proporsi Debt to Equity Ratio (DER) menyebabkan laba perusahaan tidak menentu dan menambah kemungkinan bahwa perusahaan tidak mampu memenuhi kewajiban pembayaran utangnya. Perusahaan yang memiliki nilai rasio DER yang tinggi akan mempengaruhi kepercayaan terhadap keputusan investor untuk berinvestasi dalam perusahaan tersebut. Tinggi rendahnya risiko ini secara tidak langsung dapat mempengaruhi harga saham perusahaan.

\section{Pengaruh Return on Equity (ROE) Terhadap Harga Saham}

Semakin tinggi rasio ROE makan semakin baik kinerja perusahaan dalam mengelola modalnya untuk menghasilkan keuntungan bagi para pemegang saham. Peningkatan net income akan menyebabkan nilai rasio ROE meningkat. Semakin tinggi rasio ROE maka harga saham perusahaan juga ikut meningkat

\section{Pengaruh Earning per Share (EPS) Terhadap Harga Saham}

Semakin tinggi nilai rasio EPS maka akan semakin meningkatkan tingkat kepuasan dan kepercayaan investor. Hal ini dikarenakan semakin besar laba yang disediakan untuk pemegang saham serta adanya kemungkinan peningkatan jumlah deviden yang akan diterima. Hal ini akan memberikan pengaruh positif terhadap harga saham serta meningkatkan minat investor sehingga harga saham perusahaan juga meningkat. 
Ilham (2018) mengkaji mengenai Pengaruh Return on Equity (ROE), Debt to Equity Ratio (DER), Earning per Share (EPS), Inflasi, dan BI Rate terhadap Volatilitas Saham Jakarta Islamic Index (JII). Hasil penelitian menunjukkan ROE, DER dan EPS berpengaruh signifikan terhadap volatilitas harga saham Jakarta Islamic Index (JII) pada sektor properti dan real estate.

Manopo (2017) meneliti tentang Pengaruh Current Ratio, DER, ROA dan NPM Terhadap Harga Saham Pada Perusahaan Food dan Beverages yang Terdaftar di Bursa Efek Indonesia Periode 2013- 2015. Hasil penelitian menunjukkan secara parsial hanya DER yang berpengaruh negatif signifikan terhadap harga saham.

Anwaar (2016) mengkaji tentang Impact of Firms Performance on Stock Returns (Evidence from Listed Companies of FTSE-100 Index London, UK). Secara parsial variabel EPS, ROA dan NPM berpengaruh signifikan terhadap harga saham.

Tyas dan Saputra (2016) mengkaji Analisis Pengaruh Profitabilitas Terhadap Harga Saham (Studi Kasus Perusahaan Telekomunikasi Yang Terdaftar di Bursa Efek Indonesia (BEI) Periode 2012-2014). Secara parsial variabel ROE dan EPS tidak berpengaruh signifikan terhadap harga saham.

Hermawanti, Hidayat (2015) meneliti tentang Pengaruh Earning per Share (EPS), Price Earning Ratio (PER), Debt to Equity Ratio (DER), Return on Asset (ROA) dan Return on Equity (ROE) terhadap harga saham perusahaan go public sektor property dan real estate periode 2010 - 2014. Hasil penelitian menunjukkan EPS dan ROE secara parsial berpengaruh terhadap harga saham. Sedangkan PER dan DER tidak berpengaruh terhadap harga saham.

Dari penelitian penelitan terdahulu terdapat tiga hipotesis alternatif pada penelitian ini : $\mathrm{H}_{1}$ : Debt to Equity Ratio (DER) mempunyai pengaruh yang signifikan terhadap harga saham pada perusahaan real estate dan properti yang terdaftar di Bursa Efek Indonesia periode 20152018

$\mathrm{H}_{2}$ : Return on Equity (ROE) mempunyai pengaruh yang signifikan terhadap harga saham pada perusahaan real estate dan properti yang terdaftar di Bursa Efek Indonesia periode 2015-2018 $\mathrm{H}_{3}$ : Earning per Share (EPS) mempunyai pengaruh yang signifikan terhadap harga saham pada perusahaan real estate dan properti yang terdaftar di Bursa Efek Indonesia periode 20152018

$\mathrm{H}_{4}$ : Debt to Equity Ratio (DER), Return on Equity (ROE) dan Earning per Share (EPS) secara bersama sama mempunyai pengaruh yang signifikan terhadap harga saham pada perusahaan real estate dan properti yang terdaftar di Bursa Efek Indonesia periode 2015-2018

\section{METODOLOGI PENELITIAN}

\section{Sumber dan Metode Pengumpulan Data}

Populasi penelitian ini adalah perusahaan properti dan real estate yang terdaftar di Bursa Efek Indonesia (BEI) periode tahun 2015-2018. Jumlah populasi dalam penelitian ini sebanyak 48 perusahaan. Pemilihan sampel yang dilakukan berdasarkan metode purposive sampling, yakni pengambilan sampel berdasarkan kriteria tertentu.

Penelitian ini menggunakan sumber data sekunder dimana data diperoleh secara tidak langsung dari objek yang diteliti. Data tersebut diperoleh dengan mengunduhnya dari dokumentasi Bursa Efek Indonesia (BEI) melalui website www.idx.co.id dan www.financeyahoo.com.

Dari data yang dikumpulkan dipilih data harga saham (Y) sebagai variabel terikat dan DER (X1), ROE (X2) dan EPS (X3) sebagai variabel bebas.

Secara statistik persamaan dari semua variabel adalah sebagai berikut :

$$
\mathrm{Y}=\alpha+\mathrm{b}_{1} \mathrm{DER}+\mathrm{b}_{2} \mathrm{ROE}+\mathrm{b}_{3} \mathrm{EPS}+\varepsilon
$$


Dimana :

Y : Harga Saham (Rupiah)

$\alpha \quad$ : konstanta (Intercept)

DER : Debt to Equity Ratio (Persen)

ROE : Return on Equity (Persen)

EPS : Earning per Share (Persen)

$b_{1}, b_{2}, b_{3}, \quad:$ Koefisien regresi variabel independen

\& $\quad$ : Koefisien Error

Metode analisis data dalam penelitian ini dilakukan dengan bantuan program pengolahan data Statistical Package for Social Science (SPSS) versi 24.00.

ANALISIS DAN BAHASAN TEMUAN

Berdasarkan hasil penelitian diperoleh model persamaaan sebagai berikut :

$$
\mathrm{Y}=\text { 446,637 - 21,016DER - 4,370ROE + 5,749EPS }
$$

Dari persamaan di atas dapat diperhatikan bahwa Debt to Equity Ratio memberikan kontribusi pengaruh pada harga saham sebesar -21,016. Artinya, jika DER naik satu satuan maka akan terjadi penurunan pada harga saham sebesar 21,016 dan demikian juga sebaliknya. Return on Equity (ROE) juga berkontribusi mempengaruhi harga saham sebesar -4,370 satuan. Artinya, jika ROE naik satu satuan maka akan terjadi penurunan pada harga saham sebesar 4,370 dan demikian juga sebaliknya. Earning per Share (EPS) berkontribusi mempengaruhi harga saham sebesar 5,749. Artinya, jika EPS naik satu satuan maka akan terjadi kenaikan pada harga saham sebesar 5,749 dan demikian juga sebaliknya.

Namun dari ketiga variabel bebas tersebut, secara parsial hanya hanya EPS yang memiliki pengaruh signifikan pada harga saham perusahaan real estate dan properti. Sedangkan DER dan ROE tidak mempengaruhi harga saham secara signifikan (Tabel 1).

Tabel 1

Hasil Uji t ( $t$ test)

\begin{tabular}{|l|r|r|}
\hline Model & \multicolumn{1}{|c|}{$\mathrm{T}$} & \multicolumn{2}{|c|}{ Sig } \\
\cline { 3 - 4 } & & \\
\hline 1 (Constant) & 4.589 & \\
& -1.633 & 0.106 \\
DER & -0.88 & 0.381 \\
ROE & 5.957 & 0 \\
EPS & & \\
\end{tabular}

Sumber : Hasil olah data sekunder dengan SPSS 24.00

Jika dilihat secara bersama sama, diperoleh hasil bahwa ketiga variabel bebas secara bersama sama mempengaruhi harga saham. Hal ini dapat diketahui dari tabel hasil uji F (Tabel 2). 
Tabel 2

\begin{tabular}{|c|c|c|c|c|c|c|}
\hline \multicolumn{7}{|c|}{ Hasil Uji F (F test) } \\
\hline Model & & $\begin{array}{l}\text { Sum of } \\
\text { Squares }\end{array}$ & df & Mean Square & $\mathrm{F}$ & Sig. \\
\hline \multirow[t]{3}{*}{1} & Regression & 5901242.399 & 3 & 1967080.800 & 15.131 & $.000^{\mathrm{b}}$ \\
\hline & Residual & 12480094.99 & 96 & 130000.990 & & \\
\hline & Total & 18381337.39 & 99 & & & \\
\hline
\end{tabular}

Sumber : Hasil olah data sekunder dengan SPSS 24.00

Berdasarkan hasil uji koefisien determinasi diketahui nilai $R$-squared $\left(\mathrm{R}^{2}\right)$ sebesar $32,1 \%$. Angka $\left(\mathrm{R}^{2}\right)$ yang diperoleh mendekati 0 menunjukan hubungan yang lemah. Nilai $R^{2}$ (koefisien determinasi) sebesar $32,1 \%$. Hal ini menunjukkan bahwa persentase pengaruh variabel independen (DER, ROE dan EPS) terhadap variabel dependen (Harga Saham) sebesar 32,1\%. Sementara selebihnya $67,9 \%$ dipengaruhi oleh faktor - faktor lain di luar model penelitian ini.

\section{KESIMPULAN DAN SARAN}

Kesimpulan

Berdasarkan dari hasil analisis data yang telah dilakukan, maka dapat diambil kesimpulan sebagai berikut :

1. Debt to Equity Ratio (DER) tidak berpengaruh signifikan terhadap harga saham pada perusahaan real estate dan properti yang terdaftar di Bursa Efek Indonesia periode 20152018.

2. Return on Equity (ROE) tidak berpengaruh signifikan terhadap harga saham pada perusahaan real estate dan properti yang terdaftar di Bursa Efek Indonesia periode 20152018.

3. Earning per Share (EPS) mempunyai pengaruh yang signifikan terhadap harga saham pada perusahaan real estate dan properti yang terdaftar di Bursa Efek Indonesia periode 2015-2018. Dengan semakin meningkatnya perubahan Earning per Share (EPS) maka akan semakin meningkatkan harga saham atau sebalik`nya.

4. Debt to Equity Ratio (DER), Return on Equity (ROE) dan Earning per Share (EPS) secara bersama sama mempunyai pengaruh yang signifikan terhadap harga saham pada perusahaan real estate dan properti yang terdaftar di Bursa Efek Indonesia periode 20152018.

5. Namun pengaruh semua variabel bebas diatas tidak dapat menjadi penjelasan perubahan harga saham. Hal ini karena nilai koefisien determinasinya hanya sebesar $32,1 \%$. Dengan demikian, disarankan perlunya studi lanjutan untuk mencari variabel-variabel bebas lainnya yang lebih berpengaruh terhadap harga saham real estate dan properti.

\section{Saran}

Dari hasil penelitian, maka saran yang dapat diberikan adalah sebagai berikut :

1. Hasil penelitian ini diharapkan dapat memberikan masukan bagi investor dalam melakukan investasi saham dengan melihat kondisi perusahaan salah satunya adalah melalui kinerja keuangan perusahaan.

2. Perusahaan real estate dan properti diharapkan dapat meningkatkan kinerja keuangan perusahaan dan perusahaan juga memperhatikan rasio DER, ROE dan EPS agar harga saham meningkat. 
DAFTAR PUSTAKA

Afiah, Desy. (2017). Pengaruh Suku Bunga SBI, Debt to Equity Ratio, Return on Equity, dan Earning per Share Terhadap Return Saham Perusahaan Properti dan Real Estate Jurnal Manajemen Keuangan Fakultas Ekonomi Universitas Islam Indonesia

Alwi, Iskandar Z. (2003). Pasar Modal, Teori dan Aplikasi. Jakarta : Pancur Siwah

Darmaji, Tjiptono dan Fachruddin. (2011). Pasar Modal di Indonesia. Jakarta: Salemba Empat.

Hania. (2017). Pengaruh Return on Equity (ROE), Earning per Share, dan Market Value Added Terhadap Rate of Return Saham Perusahaan Properti Yang Terdaftar di Bursa Efek Indonesia Periode 2012-2014. Tesis. Universitas Tarumanegara Jakarta

Ilham, Iqbal. (2018). Analisis Pengaruh Return on Equity, Debt to Equity Ratio. Earning per Share, Inflasi, BI Rate Terhadap Volatilitas Saham Jakarta Islamic Index Pada Perusahaan Sektor Properti dan Real Estate Periode 2013-2017. Yogyakarta: Universitas Muhammadiyyah Yogyakarta.

Jogiyanto. (2015). Teori Portofolio dan Analisis Investasi. Yogyakarta: BPFE

Pedige,M. (2016). The Impact of Financial Leverage on Firms Value. International Journal of Advancement in Engineering Technology, Management, Vol 3, Issue 7.

Perkasa, Ryan, (2016). Analisis Pengaruh ROE, EPS, PBV, DER, dan NPM Terhadap Harga Saham Pada Perusahaan Real Estate dan Properti di Bursa Efek Indonesia (BEI) Periode 2011-2013. Tesis. Magister Manajemen Universitas Tarumanegara Jakarta

Priyatno, Dwi. (2012). Belajar Cepat Olah Data Statistik dengan SPSS. Yogyakarta : CV Andi Offset

Tandelilin, Eduardus. (2010). Portofolio dan investasi: Teori dan Aplikasi. Yogyakarta : Kanisius

Tyas, Rizqi Aning, Saputra, Rishi Septa. (2016). Analisis Pengaruh Profitabilitas Terhadap Harga Saham (Studi Kasus Perusahaan Telekomunikasi Yang Terdaftar di BEI Periode 2012-2014). Jurnal Online Insan Akuntan, Vol 1 No 1, Juni 2016, hal 77-91

Undang-Undang Pasar Modal 1995, No.8 Tahun 1995. LN. No 64 Tahun 1995, TLN No.3608 www.yahoofinance.com 